\title{
Kamienie węgielne edukacji humanistycznej ${ }^{1}$
}

\section{Cornerstones of Education in the Humanities}

\begin{abstract}
The article is devoted to the basics of humanities education (especially Polish studies) in contemporary cultural conditions. The author, recalling the findings of Martha Nussbaum and Chantal Delsol, shows how important it is to rethink the purpose and value of such education, and demonstrates the different ways in which it can be approached. It is also argued that the current way of thinking about humanities education demonstrated by political decision-makers in Poland is closer to the post-totalitarian perception of reality, thoroughly presented in Vaclav Havel's essays, than to the proposals formulated by the aforementioned intellectuals.
\end{abstract}

Keywords: humanities education, post-totalitarian education, pro-democratic education, methodology of inquisitiveness, ethics of care

Streszczenie: Artykuł poświęcony jest podstawom edukacji humanistycznej (szczególnie polonistycznej) we współczesnych uwarunkowaniach kulturowych. Autor, przywołując ustalenia Marthy Nussbaum oraz Chantal Delsol, pokazuje, jak ważne jest przemyślenie celu i sensu takiej edukacji, oraz demonstruje, jak różne mogą być jej ujęcia.

Dowodzi również, że dzisiejszy sposób myślenia o edukacji humanistycznej proponowany przez decydentów politycznych w Polsce jest bliższy posttotalitarnemu postrzeganiu rzeczywistości, wnikliwie przedstawionemu w esejach Vaclava Havla, niż propozycjom sformułowanym przez wymienione intelektualistki.

Słowa kluczowe: edukacja humanistyczna, edukacja posttotalitarna, edukacja prodemokratyczna, metodyka dociekliwości, etyka troski

W naukach humanistycznych toczy się intrygująca dyskusja o istocie współczesności, w której ważne miejsce zajmuje refleksja na temat tego, czego trzeba uczyć młodych ludzi oraz jak i dlaczego należy to robić. W dyskusji tej można wyodrębnić zagadnienia skupiające na sobie szczególną uwagę. Są nimi diagnozy stawiane współczesności, formułowane na ich tle aktualne wyzwania edukacyjne

1 Tytułową formułę zapożyczyłem z książki Chantal Delsol zatytułowanej Kamienie węgielne. Na czym nam zależy?, tłum. M. Kowalska, Kraków 2018. 
oraz zagrożenia wymagające „prewencyjnego” oddziaływania ze strony tychże nauk. Ważnym elementem tego dyskursu jest refleksja nad istotą człowieczeństwa, zarówno w kontekście dynamicznych przeobrażeń dokonujących się w wielu sferach życia, jak i w kontekście tradycji filozoficznych, religijnych, kulturowych czy historycznych. Proponuję przyjrzeć się dwóm sposobom postrzegania aktualnych problemów stojących przed edukacją humanistyczną i dydaktycznym pożytkom wynikającym z ich zestawienia. Autorkami obu propozycji są kobiety mające i znaczący wpływ na przebieg wspomnianej debaty, i autorytet, który sprawia, że ich sądy są przywoływane w rozważaniach poświęconych tymże zagadnieniom ${ }^{2}$. Jedno stanowisko formułuje w swoich książkach Martha C. Nussbaum, a drugie Chantal Delsol.

\section{Metodyka dociekliwości}

Diagnozy współczesności, które przedstawia amerykańska filozof polityki i prawa, wynikają z przekonania, iż konstytutywną cechą świata jest jego niezwykła różnorodność. Stanowi ona jednak również poważne wyzwanie edukacyjne; wymaga bowiem przemyślenia sposobów, jak o niej rozmawiać, ale też jak w jej świetle rozpatrywać kwestie związane z tożsamością, obywatelskością, etyką, prawami człowieka, przynależnością do wspólnoty kulturowej, narodowej, religijnej, stosunkiem do tradycji. W ujęciu Nussbaum troska o świat jest prymarna wobec troski o to, co lokalne, narodowe, najbliższe, bezpośrednio doświadczane. Dlatego przywołuje ona kategorię obywatelskości i ją poddaje edukacyjnym rozważaniom. W książce zatytułowanej W trosce o człowieczeństwo. Klasyczna obrona reformy ksztatcenia ogólnego następującą deklaracją inicjuje swoje dalsze rozważania: „Opowiadam się za określonym wzorem obywatelstwa oraz za formułowaniem propozycji edukacyjnych w jego perspektywie" ${ }^{3}$.

Następnie osadza tę deklarację w aktualnej rzeczywistości kulturowej i geopolitycznej, z której wyprowadza edukacyjne imponderabilia:

Nasze akademie kształcą obywateli, co oznacza konieczność stawiania pytań o to, kim we współczesnych czasach powinien być i jaką mieć wiedzę dobry obywatel. Dzisiejszy świat stał się nieodwracalnie wielokulturowy i wielonarodowościowy. Rozumienie, kooperatywne rozwiązania wielu najbardziej palących problemów,

2 Zob. na przykład K. Koziołek, Czas lektury, Katowice 2017; Z.A. Kłakówna, Język polski. Wyktady z metodyki, Kraków 2016; P. Kasprzak, Z.A. Kłakówna, P. Kołodziej, A. Regiewicz, J. Waligóra, Edukacja w czasach cyfrowej zarazy, Torun 2016.

3 M.C. Nussbaum, W trosce o cztowieczeństwo. Klasyczna obrona ksztatcenia ogólnego, tłum. A. Męczkowska, Wrocław 2008, s. 3. 
wymagają dialogu łączącego ludzi o różnej przynależności narodowościowej, kulturowej i religijnej ${ }^{4}$.

Wybór kierunku humanistycznej refleksji i sposobu jej podejmowania wynika zarówno z uznania różnorodności kulturowej za immanentną właściwość współczesnego świata, jak i z przekonania, iż wiele kwestii trapiących ludzi w różnych jego częściach wymaga globalnych rozwiązań i międzykulturowego porozumienia. To z kolei skłania Nussbaum do namysłu nad rdzeniem humanistycznej edukacji, czyli nad koncepcją człowieczeństwa, jaką chcemy w szkole kształtować. Badaczka przedstawia ją za pośrednictwem idei „obywatela świata”, którą można rozumieć na dwa sposoby. Pierwszy polega na uznaniu, iż podstawową domeną lojalności jest świat; a narodowe, lokalne i grupowe formy lojalności są wobec niej drugorzędne. Drugi natomiast zakłada, że mimo różnych lojalności musimy uznawać za nadrzędną wartość ludzkiego życia i rozumieć związek z ludźmi żyjącymi daleko od nas w perspektywie powszechnych ludzkich zdolności i problemów5 . Przyglądając się bliżej propozycji Nussbaum, możemy w niej dostrzec interesującą metodycznie koncepcję namysłu nad współczesnością, którą można określić mianem metodyki dociekliwości. Amerykańska filozofka opisując jej właściwości, wyraźnie sytuuje ją w kręgu tradycji sokratejskiej:

Większość ludzi, jakich spotykał Sokrates na swojej drodze, wiodła życie intelektualnie bierne. Było to życie, w którym obiegowe przekonania decydowały o najważniejszych rzeczach, działaniach, o większości dokonywanych wyborów. Wiele z tych przekonań było prawdziwych i potencjalnie szlachetnych, ale kształcenie, zdaniem Sokratesa, nie odbywa się w wyniku przekazu płynącego od nauczyciela, lecz wiąże się z krytycznym badaniem swoich przekonań przez ucznia ${ }^{6}$.

Jest to zatem dociekliwość ukierunkowana równolegle do wewnątrz i na zewnątrz; polega na podejrzliwym i sceptycznym stosunku do norm, zasad, prawd, przekonań, sądów powszechnie uznawanych i akceptowanych, które stają się również elementem naszego światoodczuwania. Ta cecha ludzkiej natury była wyzwaniem dla Sokratesa, ale też jest wyzwaniem dla edukacji kształcącej „obywateli świata”, mających postrzegać świat jako przestrzeń, gdzie nie jesteśmy sami i gdzie inni ludzi mają swoje życie, potrzeby oraz prawo, by te potrzeby realizować 7 . Dociekliwość ma również potencjał edukacyjny, gdyż za-

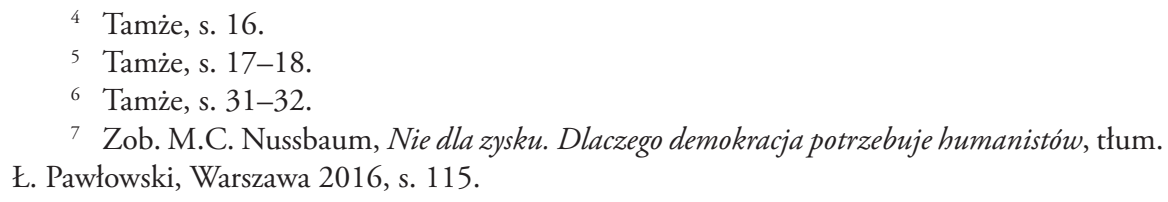


kłada, że różnorodność świata jest jego walorem, a ona sama służy wykrywaniu tego, co godne jest uwagi, zainteresowania i intelektualnej refleksji ${ }^{8}$. Z tekstów Nussbaum wynika także, że można ją w szkole stymulować. Warunkiem jest jednak nadanie uczeniu się wymiaru osobistego: „Powinno ono uwzględniać aktualną sytuację ucznia wraz z dotychczasowym stanem jego wiedzy i przekonań oraz brać pod uwagę przeszkody stojące na drodze do samopoznania i intelektualnej wolności”".

W tym kolejnym nawiązaniu do filozofii kształcenia w duchu sokratejskim badaczka zwraca uwagę, iż edukacja humanistyczna wspiera człowieka tak, by poznając świat, poznawał równolegle siebie - istnieje bowiem nierozerwalny związek między krytycznym myśleniem o rzeczywistości a krytycznym myśleniem o sobie. Warunkiem zaistnienia takiej relacji jest natomiast częste konfrontowanie uczących się z sytuacją odmienności ${ }^{10}$; to w jej świetle można dopiero dostrzec różnorodność norm i tradycji czy rozmaitość sposobów światoodczuwania.

\section{Pochwała czytania}

Dla polonisty istotne znaczenie mają w tym kontekście sugestie Nussbaum dotyczące roli literatury w owym procesie „oswajania” różnic. Amerykańska intelektualistka traktuje ją bowiem przede wszystkim jako świadectwo rozmaitych sposobów postrzegania świata, bycia w świecie, stosunku do świata. Jest więc egzystencjalnym doświadczaniem rzeczywistości i propozycją namysłu nad istotą ludzkiej kondycji: „Jeśli literatura stanowi odzwierciedlenie ludzkich możliwości, to dokonywany przez nas wybór dzieł literackich nieuchronnie będzie dostarczał odpowiedzi oraz pogłębiał rozumienie tego, kim jesteśmy i kim możemy się stać"11.

Kontakt z literaturą jako wielowariantową opowieścią o świecie i człowieku wynikającą z doświadczenia ich niezwykłej różnorodności pozwala rozwijać narracyjną wyobraźnię, czyli jedną z najważniejszych ludzkich dyspozycji. Nussbaum definiuje ją jako zdolność do stawiania się w sytuacji osoby od nas odmiennej, bycie wnikliwym czytelnikiem jej historii, rozumienie jej emocji,

8 Tak pojmowana dociekliwość wynika z ciekawości, której edukacyjny potencjał eksponował Leszek Kołakowski, stwierdzając: „Zauważmy (...), że instynkt ciekawości, szukanie nowego, fascynacja tym, co nieznane, jest to rodzaj życia, w którym zakłada się, choćby bezwiednie, pewien obraz świata, pewną "filozofię«. Zakłada się mianowicie, że świat, w którym przebywamy, świat naszego doświadczenia, jest czegoś wart". L. Kołakowski, O podróżach [w:] tegoż, Mini-wyktady o maxi-sprawach, Kraków 2006, s. 47 (wyróżn. Autora).

9 M.C. Nussbaum, W trosce o cztowieczeństwo, dz. cyt., s. 42.

10 Zob. tamże, s. 43.

11 Tamże, s. 118. 
życzeń, pragnień ${ }^{12}$. Dlatego też w dialogu dzieci i młodzieży z literaturą upatruje ona cennego narzędzia służącego formowaniu postawy obywatelskiej definiowanej jako poczucie solidarności z innymi bez względu na dzielące nas różnice:

Literacka wyobraźnia jest doskonałym przygotowaniem do etycznych działań. Nawyki empatii i snucia domysłów sprzyjają kształtowaniu pewnego typu obywatelstwa oraz określonego rodzaju wspólnoty, która pielęgnuje empatyczne udzielanie odpowiedzi na potrzeby innych oraz rozumie różne okoliczności kształtujące te potrzeby z uwzględnieniem odrębności i prywatności innego ${ }^{13}$.

Trudno amerykańskiej intelektualistce odmówić konsekwencji w jej sposobie pojmowania roli kształcenia humanistycznego we współczesnych systemach edukacyjnych. Dla niej troska o świat wyraża się w pielęgnowaniu idei demokratycznych, gdyż tylko one gwarantują możliwość wspólnego poszukiwania rozwiązań problemów, które dotyczą świata. Możliwość tę można jednak urzeczywistnić dopiero wówczas, gdy na owe problemy spojrzymy również z perspektywy innej niż nasza, przekraczając lokalne (narodowe) partykularyzmy. Nie zaskakują w tym kontekście edukacyjne cele, które Nussbaum wymienia w książce Nie dla zysku. Są nimi:

zdolność do krytycznego myślenia i wykroczenia poza więzy lokalne i spojrzenia na globalne problemy z perspektywy „obywatela świata”, wreszcie zdolność do współodczuwania i zrozumienia trudnej sytuacji drugiej osoby ${ }^{14}$.

Jej zdaniem to właśnie duch humanistyki pozwala odważnie myśleć, rozumieć doświadczenia będące udziałem człowieka, a także złożoność świata, w którym żyjemy ${ }^{15}$.

\section{„Prewencyjność” edukacji humanistycznej}

Analizę tego sposobu postrzegania sensu i funkcji edukacji humanistycznej warto uzupełnić wyliczeniem zagrożeń, którym owa edukacja ma zapobiegać. Są to zagrożenia dla demokracji i pokojowego, międzykulturowego dialogu,

12 Tamże, s. 19.

13 Tamże, s. 101. Nussbaum nie waha się również przed przypisaniem tak pojmowanemu wychowaniu literackiemu znaczenia politycznego: „Politycznym zadaniem literatury jest przenoszenie nas takim, jacy jesteśmy, w życie innego, odkrywanie zarówno podobieństw, jak i głębokich różnic pomiędzy jego a naszymi sposobami życia i myślenia oraz czynienie ich bardziej zrozumiałymi”. Tamże, s. 123.

14 M.C. Nussbaum, Nie dla zysku, dz. cyt., s. 23.

15 Tamże. 
utrudniające wzajemną komunikację i kształtowanie postawy solidarności z innymi. Nussbaum w tym kontekście wymienia pokusę postrzegania rzeczywistości i odmienności kulturowych wyłącznie przez pryzmat własnej kultury, co zwykle kończy się pozytywnym dowartościowaniem tego, co lokalne, własne, narodowe, oraz zdystansowaniem się i obojętnością czy jawną wrogością wobec tego, co inne, obce, dalekie. Za groźny uważa również brak zdolności do myślenia krytycznego, komunikowania się z innymi i postrzegania własnych problemów właśnie z perspektywy innych. Nic dziwnego zatem, iż dociekliwości przeciwstawia ona intelektualną bierność, która w sprzyjających warunkach może przeobrazić się w nienawiść wynikającą z braku akceptacji tego, co odmienne, wymierzoną również w tych, którzy przez swą dociekliwość budzą niepokój i naruszają intelektualną strefę komfortu członków danej wspólnoty (o czym dobitnie przekonał się na przykład Sokrates).

Nussbaum stanowczo sprzeciwia się również redukowaniu człowieczeństwa do wymiaru ekonomicznego. Jej zdaniem edukacja nie może być podporządkowana osiąganiu gospodarczych zysków, a tezę, że wzrost gospodarczy sam z siebie prowadzi do większej demokratyzacji, uważa (przywołując przykład Chin) za wyjątkowo naiwną. Kwestionuje także oczywisty dla wielu związek między takim wzrostem a równoległym kształtowaniem się świadomości obywatelskiej zaangażowanej w sprawy publiczne, otwartej na dyskusję i odmienność perspektyw oraz solidarnej z innymi. Jej bezkompromisowość w tej kwestii idzie w parze z troską o jakość edukacji humanistycznej, która jest zagrożeniem dla każdego porząadku eliminującego myślenie z przestrzeni publicznej:

Łatwiej traktować ludzi jak przedmioty, którymi można manipulować, jeśli nikt nigdy nie nauczył nas patrzeć na nich w odmienny sposób. Jak powiadał Tagore, agresywny nacjonalizm musi stępić poczucie moralności, a zatem potrzebuje ludzi, którzy w drugim człowieku nie widzą indywiduum, posługują się językiem dominującym w danej zbiorowości, postrzegają świat jak potulni biurokraci i tak też się zachowują ${ }^{16}$.

\section{Etyka troski (o świat)}

Z odmiennej perspektywy współczesnemu światu przygląda się Chantal Delsol. Ta francuska intelektualistka interesująca się filozofią polityczną, historią idei i antropologią filozoficzną w książce Kamienie wegielne. Na czym nam zależy? opisuje go jako świat rozproszonych i sprzecznych zasad. Zwraca uwagę, iż cywilizacja Zachodu przeżywa kryzys swojej tożsamości, tym bardziej 
widoczny, im mocniej odżegnuje się od wartości tę tożsamość od dwóch tysięcy lat kształtujących, czyli tych, które składają się na dziedzictwo kultury śródziemnomorskiej. Diagnozując stan kryzysu i niespójności, formułuje jednak tezę o konieczności zatroszczenia się o świat i jego przyszłość: „Skoro już tu jesteśmy, to niezależnie od jakichkolwiek wierzeń religijnych naszą rolą jest przynajmniej nie zniszczyć tej sceny, na której żyć będą nasi następcy, lecz raczej ją ulepszyć" ${ }^{17}$.

Francuska filozofka świadoma kryzysu europejskiej (zachodniej) tożsamości, wyrażającego się chociażby w sceptycznym i zdystansowanym podejściu do dziedzictwa chrześcijańskiego, domaga się refleksji nad fundamentami naszej cywilizacji, czyli tytułowymi kamieniami węgielnymi. We współczesnej rzeczywistości kulturowej dostrzega szczególnie potrzebę kształtowania świadomości obywatelskiej. Interesujące w tej perspektywie jest zaproponowane przez Delsol rozumienie istoty demokracji (obywatelskiej):

w tym właśnie jedynym znaczeniu rozumiemy demokratyczną równość: obywatele nie są naturalnie równi względem inteligencji czy kompetencji, ale są równi pod względem dojrzałości, to znaczy zdolności do dostrzegania tragizmu ludzkiej kondycji. Jako wyjście z dzieciństwa wiek dorosły jest wyjściem z niewinności i ze spokojnego postrzegania świata, w którym nie widać dramatu. Dorosły obywatel zna dramat i mierzy się z nim. Niedorosły poddany czeka, by to rząd rozpoznał dramat i znalazł za niego odpowiedź; traktowany jak dziecko pozostaje w zamkniętym świecie dzieciństwa, chroniony, czasem rozpieszczany, a czasem arbitralnie karany ${ }^{18}$.

Pisząc o obywatelskości i stosunku człowieka do własnej kultury oraz świata, w którym żyje, Delsol podkreśla, że wymaga to postawy „żarliwości wobec swojego własnego świata" ${ }^{19}$. Wyraża ona w ten sposób przekonanie, iż świat jest wart tego, by się o niego troszczyć i ocalić przed zniszczeniem. Z uznaniem wypowiada się o dostrzeganej współcześnie „etyce troski, która chce dbać, naprawiać, czuwać nad światem, zamiast go zmieniać"20.

17 Ch. Delsol, Kamienie węgielne, dz. cyt., s. 16. Wyrazem tej troski jest chociażby postawa proekologiczna wynikająca z odkrycia „zewnętrznego wobec nas porządku, który musimy szanować pod groźbą wyginięcia”. Tamże, s. 23.

18 Tamże, s. 95.

19 Tamże, s. 212.

20 Tamże, s. 107. 


\section{Edukacyjne priorytety według Delsol}

Aby troska o świat była urzeczywistniana, potrzebne są jednak odpowiedzialność, wiedza, świadomość wzajemnej zależności człowieka i świata. I właśnie w tym wymiarze Delsol dostrzega istotną rolę edukacji. Analizując jej poglądy wyłożone w książce Kamienie węgielne, można wyodrębnić cztery edukacyjne priorytety pozwalające na urzeczywistnienie wspomnianej etyki troski. Pierwszym z nich jest afirmacja inicjatywy jako sposobu funkcjonowania w świecie. Opisując jej swoistość, francuska filozofka przeciwstawia ją inicjacji.

Inicjacja oznacza, że pewien korpus wiedzy i praktycznych umiejętności zostaje przekazany jednostce w odpowiednim wieku po to, by je odtwarzała. Inicjowany niczego nie podważa, w przeciwnym razie wypadłby z systemu. Kształcenie inicjatywy natomiast prowadzi do powstania podmiotów, które uczą się władać pewnym zasobem wiedzy i go krytykować ${ }^{21}$.

Temu dydaktycznie interesującemu rozróżnieniu towarzyszy kolejny edukacyjny priorytet przejawiający się w trosce o wychowanie człowieka wolnego i zarazem odpowiedzialnego za swoje czyny:

Osoba jest istotą ludzką odłączoną od grupy, nie w tym sensie, że staje się niezależna (to złudzenie nadmiernego indywidualizmu), ale w tym sensie, że uważa się ją za zdolną do samodzielnego kształtowania swojego losu, do podejmowania działań, które zależą tylko od niej, i do ponoszenia ich konsekwencji. Dlatego mogła rozwinąć się demokracja. Podmiotowość oznacza, że każdy człowiek jest obdarzony sumieniem, wewnętrznym zakamarkiem zdolnym przeciwstawić się władzy, prawu pozytywnemu, opinii publicznej ${ }^{22}$.

Słowa te można potraktować jako swoistą pochwałę wychowania obywatelskiego, w którym krytyczne myślenie łączy się z wolą działania i ponoszeniem za nie odpowiedzialności (także moralnej), a nawet, jeśli to konieczne, za cenę obywatelskiego nieposłuszeństwa. Dla Delsol istnieje ścisły związek między

21 Tamże, s. 98. W pedagogice można jednak odnaleźć inne ujęcie inicjacji, które jest ukazywane jako pozytywna wartość edukacyjna. Ciekawą wykładnię tego sposobu rozumienia przedstawia Krzysztof Maliszewski w książce Pedagogika na pograniczu światów. Eseje z cyklu „Medium Mundi”, Katowice 2015. W rozdziale „Inicjacyjna struktura wychowania (inspiracje Eliadowskie)” pisze on między innymi: „Kształcenie - o ile jest w istocie kształcące, czyli przybiera formę inicjacyjną - to nie proste znalezienie się w sytuacji nauczania, nie pokonanie jakiegoś formalnego szczebla oświatowego, nie dodanie do swoich zasobów nowej puli informacji lub nowej umiejętności, ale przewartościowanie, otwarcie horyzontu, przemiana stylu bycia. Jak wyjaśniał Eliade, inicjacja to przejście z jednego świata do drugiego, czyli transformacja ontologiczna”. Tamże, s. 44 (wyróżn. Autora). Ten sposób rozumienia inicjacji jest odmienny od tego, który proponuje Delsol, a zaskakująco bliski temu, co określa ona mianem inicjatywy.

22 Ch. Delsol, Kamienie wegielne, dz. cyt., s. 105. 
demokracją a tak pojmowaną rolą jednostki, w czym widać wyraźnie intelektualne podobieństwo do koncepcji przedstawianych przez Hannah Arendt, a wynikających z jej fascynacji grecką polis ${ }^{23}$.

Trzecim priorytetem jest podkreślanie związków między człowiekiem a światem, a szczególnie tego, że człowiek ów świat zamieszkuje (jak dom) i jest zobowiązany go szanować (gdyż świat jest starszy niż on sam i stanowi dom również dla tych, którzy pojawią się na nim po naszej śmierci $\left.{ }^{24}\right)$. Wszystko, co człowiek myśli, czyni, tworzy, mówi, wynika z jego relacji wobec świata. I dlatego Delsol domaga się namysłu nad owymi relacjami:

Trzeba przywrócić pojęcie „świata”: nie jest to teatralna dekoracja ustawiona za postacią, która ostatecznie mogłaby się bez tego obejść, lecz atmosfera, którą ta postać oddycha, sieć, którą się stale żywi i bez której byłaby niczym ${ }^{25}$.

Czwartym (ale nie najmniej ważnym) priorytetem jest ukazywanie młodzieży, a nawet dzieciom, ważnych egzystencjalnych pytań, jak również stopniowe odsłanianie dramatycznego wymiaru ludzkiego życia ${ }^{26}$, co ma, zdaniem Delsol, przygotować ich do dojrzałego funkcjonowania w dalszym życiu:

Jeden z celów wychowania polega na stopniowym odsłanianiu dramatów, z których utkane jest istnienie, aby dziecko uczyło się je pokonywać i wyrobiło w sobie niezbędne zaufanie, a zarazem odwagę. Utrzymywanie dziecka w złudzeniu egzystencji pewnej i stabilnej jest równoznaczne ze skazywaniem go na wieczną opiekę. Tym samym wychowawcy, którzy realizują tego rodzaju program, sprzyjają rządom autorytarnym. Dlatego rząd prawdziwie demokratyczny wymaga czegoś odwrotnego: wychowania do autonomii ${ }^{27}$.

Priorytety edukacyjne opisane przez Delsol odpowiadają proponowanej przez nią koncepcji postrzegania rzeczywistości:

Czy jesteśmy właścicielami rzeczywistości? Nie. Rzeczywistość stawia opór, co odkrywają obywatele państw totalitarnych, przerażeni negowaniem rzeczywistości. Jednak ta obiektywna rzeczywistość nie powinna również przerażać nas i przytłaczać, bo nigdy nie jest całkowicie obiektywna, nie jest jak przedmiot, który nam się narzuca, ponieważ to my ją myślimy, co znaczy, że w pewien sposób konstytuujemy

23 Zob. H. Arendt, Kondycja ludzka, tłum. A. Łagodzka, Warszawa 2010, s. 229-230.

24 W tej tezie również pobrzmiewają nawiązania do poglądów Arendt. Zob. tamże, s. 75.

25 Ch. Delsol, Kamienie wegielne, dz. cyt., s. 113.

26 Na znaczenie wychowania dramatycznego zwracała uwagę Irena Wojnar, a także przywołująca ją w opisie swojej koncepcji kształcenia humanistycznego Zofia Agnieszka Kłakówna. Zob. taż, Przymus i wolność. Projektowanie procesu ksztatcenia kulturowej kompetencji, Kraków 2003, przypis 146, s. 66-67.

27 Ch. Delsol, Kamienie wegielne, dz. cyt., s. 132-133. 
ją jako taką. Przede wszystkim jednak dlatego, że nie tylko ją myślimy, ale też do niej należymy ${ }^{28}$.

Dla Delsol edukacja jest więc nauką postrzegania świata, a nie zdobywaniem twardej wiedzy, jej reprodukowaniem czy przywoływaniem oficjalnych wykładni. Nie oznacza to oczywiście zerwania z przeszłością; wręcz przeciwnie, edukacja to także rozpoznawanie tradycji we współczesności oraz poszukiwanie w niej pytań i odpowiedzi, które człowiek stale ponawia ${ }^{29}$. Tej koncepcji odpowiada adekwatna do niej inna ważna idea: „Kultura jest budowlą myśli, lub jeśli ktoś woli, założeń, które tworzą sens" ${ }^{30}$.

Delsol, podobnie jak Nussbaum, prezentując swój pomysł na to, jak podejmować namysł nad otaczającym nas światem, podkreśla, iż jest to jednocześnie odpowiedź na próby odebrania człowiekowi jego godności i uproszczenia towarzyszących mu od zawsze dylematów egzystencjalnych. Dlatego ostro wypowiada się także na temat tych współczesnych nurtów określających istotę człowieczeństwa, które eksponują niezależność człowieka, jego sprawczą moc i niepodzielną władzę nad stworzeniem. Nazywa to zjawisko „bezczelnym humanizmem” i „rozszalałym antropocentryzmem” ${ }^{31}$ i ostrzega, iż przypisywanie sobie władzy bez odpowiedzialności ma charakter totalitarny i prędzej czy później oznacza konieczność zmierzenia się z konsekwencjami swoich czynów, często dla człowieka niszczącymi. Interesująca z dydaktycznego punktu widzenia jest również jej krytyka nowoczesnej racjonalności, nieufnej w stosunku do tego, co nieprzewidywalne i nieoczekiwane, a przywiązanej do porządkowania i klasyfikowania, gdzie „wszystko, co się zdarza, natychmiast musi trafić do jakiejś przegródki" ${ }^{32}$. Delsol elementy takiej racjonalności dostrzega w dwudziestowiecznych totalitaryzmach, które rzeczywistość wymyślały i w ten sposób nad nią panowały. Rozpoznawanie rzeczywistości jest tymczasem zupełnie czymś innymi niż jej dekretowanie - polega bowiem na formułowaniu pytań, na odkrywaniu tego, co niepewne i nieustalone, na fascynacji wieloznacznością, a nie na przedstawianiu gotowych, jednoznacznych, pewnych odpowiedzi.

28 Tamże, s. 237.

29 Delsol dodaje też istotną w tym kontekście uwagę: „nie oczekuje się, że jednostki będą recytować z pamięci tradycyjne lub oficjalne teksty, ale że nauczą się interpretować świat, wcześniejszą wiedzę, tradycję i dawne przekonania”. Tamże, s. 239. Temu zagadnieniu Delsol poświęciła inną swoją książkę - zob. taż, Czym jest cztowiek? Kurs antropologii dla niewtajemniczonych, tłum. M. Kowalska, Kraków 2011.

30 Taż, Kamienie wegielne, dz. cyt., s. 296.

31 Tamże, s. 83.

32 Tamże, s. 167. 


\section{Edukacja posttotalitarna a edukacja prodemokratyczna}

Tymczasem w przyjętej w styczniu 2018 roku podstawie programowej do liceum zaskakuje nie tylko brak całościowej i spójnej diagnozy współczesnej sytuacji kulturowej, proponującej namysł nad nią na przykład w duchu rozważań Nussbaum czy Delsol. Zadziwia i niepokoi również nieobecność odwołań do tradycji dydaktycznej, w której warto poszukiwać odpowiedzi, jak, czego i dlaczego warto uczyć (się), a także zupełne pominięcie doświadczeń związanych z funkcjonowaniem szkolnictwa powszechnego w czasach ideologicznego zniewolenia. A przecież obalenie komunistycznego porządku zawdzięczamy między innymi również realizowanej przez poszczególnych nauczycieli szkolnych i akademickich koncepcji kształcenia humanistycznego alternatywnej wobec tej, która oficjalnie w szkole obowiązywała, i rozwiązaniom metodycznym, za pomocą których udało się kształtować młode umysły w duchu niezależnego, podmiotowego i krytycznego myślenia ${ }^{33}$. Idee takie jak solidarność, godność, prawa człowieka, wolność słowa, obywatelstwo, podmiotowość składają się na chlubne dziedzictwo polskiej dydaktyki z tego właśnie mrocznego okresu polskiej historii i naprawdę trudno zrozumieć, dlaczego nie zostały one wyeksponowane (adekwatnie do współczesnych realiów) w tak ważnym dla edukacji dokumencie.

Potrzebne są dzisiaj refleksja i debata nad całościową koncepcją kształcenia humanistycznego przynoszące odpowiedź na pytanie zasadnicze - czy akceptujemy model edukacji posttotalitarnej, aktualnie obowiązujący, czy jednak spróbujemy wypracować i urzeczywistnić model edukacji prodemokratycznej? Aby uzasadnić tezę, że polscy uczniowie, nauczyciele i szkoła funkcjonują w systemie posttotalitarnym, warto przypomnieć, co o swoistości tegoż systemu pisał w 1978 (!) roku Vaclav Havel w słynnym eseju Sita bezsilnych ${ }^{34}$. Według niego jego konstytutywną cechą jest wymaganie monolityczności, uniformizmu i dyscypliny oraz udawanie, że proponowane $w$ jego ramach rozwiązania wynikają z potrzeb życia. W systemie tym preferuje się przynależność do wspólnoty (najczęściej wyobrażonej i wykreowanej ${ }^{35}$ ), kosztem autonomii jednostki, zupełnie ignorując indywidualne pytania, wątpliwości, rozterki, a właściwie znosząc potrzebę ich wyrażania. Havel mocno akcentuje jeszcze inną cechę, jakże widoczną we współczesnej polskiej szkole: „system posttotalitarny jest wprost opętany potrzebą ujmowania wszystkiego w regulaminy: życie jest

33 Zob. M. Sienko, Polonistyka szkolna w gorsecie ideologii. Dyskusje wokót wychowania literackiego w latach 1944-1989, Kraków 2002.

${ }_{34}$ V. Havel, Sita bezsilnych [w:] tegoż, Sita bezsilnych i inne eseje, tłum. A. Holland, Warszawa 2011, s. 87-158.

35 Zob. B. Anderson, Wspólnoty wyobrażone. Rozważania o źródtach i rozprzestrzenianiu się nacjonalizmu, tłum. S. Amsterdamski, Warszawa 1997. 
w nim na wskroś przeniknięte plątaniną przepisów, rozporządzeń, wytycznych, norm, zarządzeń i reguł" 36 .

Edukacja posttotalitarna jest więc edukacją odpowiedzi i inicjacji (według rozumienia Delsol), w przypadku języka polskiego składającą się ze szczegółowych i bardzo rozbudowanych wymagań z zakresu historii literatury, poetyki, teorii literatury, nauki o języku i fragmentarycznych odniesień do nauki języka oraz obszernej listy lektur. Te z kolei podporządkowane są systemowi egzaminacyjnemu roszczącemu sobie prawa do opisywania oczekiwanych i urzeczywistnionych kompetencji, przywiązanemu niezwykle do standaryzacji, traktującemu uczących się i tych, którzy nauczają, jako jednolitej zbiorowości, podlegających równie jednolitym kryteriom oceny pozwalającym porównać ich dokonania bez względu na warunki i konteksty, w jakich przychodzi im swoje zadania realizować. Zza warstwy szczytnych, ogólnych edukacyjnych idei, aksjologicznie nacechowanych oczekiwań i drobiazgowo wyliczonych treści oraz lektur nie wyłania się jednak żadna spójna koncepcja edukacji humanistycznej, która miałaby być realizowana w obecnych kontekstach kulturowych, społecznych, geopolitycznych, gospodarczych itd. Obowiązująca od roku wizja (?) kształcenia humanistycznego nie zawiera również zdiagnozowanych aktualnych wyzwań i potrzeb edukacyjnych ani analiz uzasadniających trafność i sensowność proponowanych rozwiązań i treści nauczania. Próżno znaleźć w niej odniesienia do problemów lokalnych, narodowych, europejskich, globalnych wymagających poddania ich edukacyjnej refleksji w rozmaitych możliwych perspektywach. Zamiast spójnego zaplecza aksjologicznego, czyli takiego, który pozwala zrekonstruować filozofię nauczania integrującą warstwę praktyczną z określoną wizją człowieczeństwa, zamieszczono zestawienie różnych nazw wartości, które nie wchodzą ze sobą we wzajemne relacje.

Jak podejmować namysł nad istotą człowieczeństwa, nie nazywając po imieniu niepokojów XXI wieku? Ksenofobia, agresywny nacjonalizm utożsamiany często z gorliwym patriotyzmem, praktyki dyskryminacyjne, kryzysy: migracyjny i klimatyczny, wszechobecna dezinformacja, ideologizacja wielu sfer ludzkiego życia, komercjalizacja świata wartości, powszechna niechęć do czytania, ignorowanie tradycji i przeszłości, fascynacja współczesnymi technologiami, ekspansja myślenia fundamentalistycznego, przemoc i agresja językowa w debacie publicznej, niechęć do Innego, instrumentalne wykorzystywanie religii oraz historii, strach przed kulturową różnorodnością, zatarcie granic między informacjami a opiniami, polityczna nowomowa, wpływ mediów społecznościowych na decyzje podejmowane w obszarze publicznym, nowe sposoby komunikowania się a prawo do prywatności i wolności słowa - to tylko przykładowa lista problemów, jakimi współczesna edukacja humanistyczna powinna się zainteresować. 
Aby to jednak było możliwe, konieczne jest zaproponowanie alternatywnego (do posttotalitarnego) modelu kształcenia humanistycznego, który nie może być korektą modelu dotychczas obowiązującego, ale zupełnie nową filozofią nauczania (zakorzenioną jednak w dobrej tradycji dydaktycznej). Powinien on być częścią całego systemu, który można by nazwać edukacją prodemokratyczną. Opis jej założeń również warto wyprowadzić ze wspomnianego eseju Havla, w którym objaśniał on, jak wielką wartość obywatelską mają pluralizm, różnobarwność (rozumiana jako różnorodność), niezależność i samoorganizacja. Ofertę edukacyjną należałoby połączyć z diagnozą rzeczywistości kulturowej i uzupełnić przykładowymi rozwiązaniami systemowymi i dydaktycznymi służącymi jej objaśnianiu. W centrum natomiast trzeba by usytuować człowieka jako istotę dramatyczną, rozdartą między uniwersalnymi troskami egzystencjalnymi (których znaczenie podkreśla Delsol) a pragnieniem przynależności do wspólnoty (co z kolei mocno akcentuje Nussbaum). Edukacja prodemokratyczna powinna to rozdarcie przybliżać, a nie je znosić lub udawać, że go nie ma. Zadaniem kształcenia literackiego byłoby więc ukazywanie człowieka jako istoty z jednej strony poświęcającej swoje życie temu, co pragmatyczne, materialne, co przynosi wymierne korzyści, a z drugiej jako istoty wykraczającej poza siebie, dążącej do własnej, indywidualnej suwerenności ideowej i moralnej. Ponadczasowo brzmią w tym kontekście słowa Havla, które można potraktować jako humanistyczne credo stanowiące kamień węgielny współczesnej edukacji:

Bardziej niż kiedy indziej i niż gdzie indziej za punkt wyjścia trzeba będzie przyjąć człowieka, ludzką egzystencję, podstawową rekonstrukcję pozycji człowieka w świecie, jego stosunku do siebie samego, do innych ludzi, do wszechświata. Powstanie lepszego modelu gospodarczego i politycznego musi dziś chyba bardziej niż kiedy indziej wyrastać z głębszej egzystencjalnej i moralnej przemiany społeczeństwa ${ }^{37}$.

Prodemokratyczna edukacja musi jednak być także edukacją proobywatelską. Havel, podobnie jak Nussbaum czy Delsol, wskazywał, że sama wolność wyrażania poglądów i związana z nią różnorodność nie chronią ludzi przed ideologią i instrumentalnym traktowaniem, nawet w społeczeństwach demokratycznych. Wolność ta jest bowiem tak samo zagrożona jak w systemach totalitarnych, zwłaszcza przez pokusę konsumpcjonizmu ${ }^{38}$ czy bezrefleksyjnego oczarowania techniką ${ }^{39}$. Dlatego tak ważne jest kształtowanie odpowiedzialności; tylko w perspektywie tej wartości wolność nabiera właściwego sensu. Autor eseju Sita bezsilnych pisze wprost o kryzysie demokracji, którego symptomem

\footnotetext{
37 Tamże, s. 115.

38 Tamże, s. 108

39 Tamże, s. 151.
} 
jest kryzys myślenia obywatelskiego polegający na tym, że człowiek „nie potrafi wyjść poza troskę o zdobywanie środków do życia i stać się dumnym oraz odpowiedzialnym członkiem "polis», realnie partycypującym w kształtowaniu jej losów" ${ }^{30}$.

Zastanawia, dlaczego w trzydziestoośmiomilionowym kraju, szczycącym się tym, że jego obywatele byli w awangardzie narodów, którym udało się to, co wydawało się niemożliwe, czyli obalić system totalitarny, i w państwie, w którym żywe do dzisiaj są tradycje walki z komunizmem i nazizmem oraz społecznego buntu wobec ideologicznej nowomowy i przemocy (realnej i symbolicznej) jako narzędzia sprawowania władzy, nie udało się zaproponować pod koniec drugiej dekady XXI wieku nowoczesnej, odpowiadającej współczesności i jej wyzwaniom, koncepcji humanistycznego kształcenia. W zamian sięgnięto po wzorce typowe dla systemu posttotalitarnego. Zmarnowano w ten sposób również możliwość wykorzystania doświadczeń ruchów dysydenckich stanowiących przecież piękny wkład w europejską refleksję nad wartością demokracji i obywatelskości. Aby zrozumieć tę utraconą szansę, warto jeszcze raz przywołać Havla. Następująco opisywał on wpływ tychże ruchów na namysł nad istotą humanizmu, także w perspektywie edukacyjnej:

demonstrują życie w prawdzie jako jedną z możliwości dla człowieka i społeczeństwa, i oczyszczają dlań przestrzeń; pomagają - choć naturalnie nie wprost - rozwijać samowiedzę obywateli: rozbijają świat pozorów i demaskują prawdziwy charakter władzy. Nie biorą na siebie mesjanistycznej roli jakowejś „awangardy” czy „elity” społecznej - tej, która jedna najlepiej wie, jak się rzeczy mają, i której misją jest „uświadamianie” „nieuświadomionych” mas (również takie zarozumiałe widzenie samego siebie jest cechą z gruntu innego sposobu myślenia - tych, którzy uważają, że mają „idealny projekt”, jak też prawo, by narzucać go społeczeństwu); nie zamierzają także nikomu przewodzić: pozostawiają każdemu swobodę decyzji, co jeśli w ogóle cokolwiek - wziąć z ich doświadczenia i działań ${ }^{41}$.

To nie dyskusja nad obecnością jednego czy drugiego tekstu w spisie lektur, to nie debata nad strukturą egzaminu, to nie rozważania nad tym, czy możliwe jest zrealizowanie wszystkich zapisanych w podstawie programowej wymagań, to nie analiza szczegółowych propozycji podręcznikowych są dzisiaj polskiej edukacji potrzebne. Konieczna jest natomiast, odwołując się do tytułu książki Delsol, refleksja nad jej kamieniami węgielnymi, nad tym, na czym nam najbardziej zależy, czyli nad tym, czy chcemy urzeczywistniać metodykę dociekliwości i etykę troski, czy reprodukować w szkole przekazywaną wiedzę; czy wybieramy edukację posttotalitarną, czy prodemokratyczną; czy chcemy wychowywania dla zysku, czy wychowania dramatycznego, edukacji odpowiedzi,

40 Tamże, s. 153.

41 V. Havel, dz. cyt., s. 144. 
czy pytań, inicjacji, czy inicjatywy. Innymi słowy, czy chcemy żyć w polis, czy w państwie opiekuńczym, proponującym intelektualne bezpieczeństwo, ale odbierającym odpowiedzialność i prawo do podejmowania ryzyka samodzielnych poszukiwań, a nawet do błądzenia.

\section{Bibliografia}

Anderson B., Wspólnoty wyobrażone. Rozważania o źródtach i rozprzestrzenianiu się nacjonalizmu, tłum. S. Amsterdamski, Warszawa 1997.

Arendt H., Kondycja ludzka, tłum. A. Łagodzka, Warszawa 2010.

Delsol Ch., Czym jest cztowiek? Kurs antropologii dla niewtajemniczonych, tłum. M. Kowalska, Kraków 2011.

Delsol Ch., Kamienie wegielne. Na czym nam zależy?, tłum. M. Kowalska, Kraków 2018.

Havel V., Sita bezsilnych [w:] tegoż, Sita bezsilnych i inne eseje, tłum. A. Holland, Warszawa 2011.

Kasprzak P., Kłakówna Z.A., Kołodziej P., Regiewicz A., Waligóra J., Edukacja w czasach cyfrowej zarazy, Toruń 2016.

Kłakówna Z.A., Jezyk polski. Wykłady z metodyki, Kraków 2016.

Kłakówna Z.A., Przymus i wolność. Projektowanie procesu ksztatcenia kulturowej kompetencji, Kraków 2003.

Kołakowski L., O podróżach [w:] tegoż, Mini-wyktady o maxi-sprawach, Kraków 2006.

Koziołek K., Czas lektury, Katowice 2016.

Maliszewski K., Pedagogika na pograniczu światów. Eseje z cyklu „Medium Mundi”, Katowice 2015.

Nussbaum M.C., Nie dla zysku. Dlaczego demokracja potrzebuje humanistów, tłum. Ł. Pawłowski, Warszawa 2016.

Nussbaum M.C., W trosce o cztowieczeństwo. Klasyczna obrona ksztatcenia ogólnego, tłum. A. Męczkowska, Wrocław 2008.

Sienko M., Polonistyka szkolna w gorsecie ideologii. Dyskusje wokót wychowania literackiego w latach 1944-1989, Kraków 2002. 